\title{
POLYMORPHISMS IN THE P53 PATHWAY GENES AND MICRONUCLEUS OCCURRENCE IN CHINESE VINYL CHLORIDE-EXPOSED WORKERS
}

\section{YONG LI' ${ }^{1}$, NAN-NAN FENG ${ }^{1}$, GUANG-HUI ZHANG ${ }^{1}$, QI WANG ${ }^{1}$, YAN-HUI HAO ${ }^{1}$, YA-NANZHANG ${ }^{1}$, CHANGXU LONG ${ }^{2}$, YONGLIANG LI ${ }^{2}$, PAUL W. BRANDT-RAUF ${ }^{2}$, and ZHAO-LIN XIA ${ }^{1}$}

${ }^{1}$ Fudan University, Shanghai, China

Department of Occupational Health and Toxicology, School of Public Health

${ }^{2}$ University of Illinois, Chicago, USA

School of Public Health

\begin{abstract}
Objectives: To investigate the association between polymorphisms in the p53 pathway genes and chromosomal damage in vinyl chloride (VC)-exposed workers. Materials and Methods: Cytokinesis block micronucleus test was performed in 310 VC-exposed workers and 149 non-exposed workers to determine chromosomal damage. The polymerase chain reaction and restriction fragment length polymorphism technique were used to detect six SNPs in the p53 pathway genes involved in the cell cycle. Results: There was a highly significant dose-response relationship between VC exposure and chromosomal damage. Individuals carrying the variant genotypes were at higher risk for chromosomal damage compared with their wild type genotype: p53rs1042522, MDM2 Del1518rs3730485, MDM2rs2279744 and GADD45Ars532446. On the other hand, individuals possessing the variant genotype of CDKN2A rs3088440 had significantly decreased risk compared with the corresponding wild-type. Conclusions: Genetic polymorphisms in P53 pathway genes may have an impact on VC-induced chromosomal damage.
\end{abstract}

Key words:

VC, Occupational exposure, p53 pathway genes, Genetic polymorphism

\section{INTRODUCTION}

Vinyl chloride monomer (VC) is commonly used in the plastics industry to produce polyvinyl chloride (PVC) which has wide usage in resins, packaging materials, and wire and cable coatings, among others [1]. In 1987, the International Agency for Research on Cancer (IARC) classified vinyl chloride (VC) as a confirmed human carcinogen based on its association with hepatic angiosarcomas [2].
$\mathrm{VC}$ is easily absorbed through the respiratory tract and diffuses into the blood. Following absorption, $\mathrm{VC}$ is metabolized by human liver cytochrome P4502E1 (CYP2E1) to the reactive intermediate chloroethylene oxide (CEO). The unstable CEO can rearrange spontaneously to chloroacetaldehyde (CAA) [3]. Both of these metabolites interact with DNA to form DNA adducts and induce errors during DNA and RNA synthesis. Previous studies showed that VC exposure

The study has been supported by the Natural Science Foundation of China (NSFC 30671740), Shanghai Bureau of Public Health (08GWD12, 08GWZX0402), NIOSH (R01-OH04192) and Graduate Student Innovation Foundation of Fudan University.

Received: February 8, 2013. Accepted: September 5, 2013.

The first 3 authors have contributed equally to this work.

Corresponding author: Z. Xia, Department of Occupational Health and Toxicology, School of Public Health, Fudan University, 138 Yixueyuan Road, Shanghai 200032, China (e-mail: zlxia@shmu.edu.cn). 
is associated with increased genotoxicity in humans such as chromosome aberrations, micronuclei (MN) and DNA strand breaks [4]. However, individual variations in response to the exposure have been noticed, and these variations may be due to genetic differences in the formation or removal of VC-DNA adducts. Susceptibility to genotoxicity may be modulated by the genetic polymorphisms of metabolic enzymes, DNA repair proteins and cell-cycle control proteins. The p53 pathway is composed of a network of genes that respond to a variety of intrinsic and extrinsic stress signals that affect cellular mechanisms monitoring DNA replication, chromosome segregation and cell division. The p53 gene is a tumor suppressor gene that plays a central role in preventing carcinogenesis by acting as a transcription factor to induce cell cycle arrest and apoptosis. It is one of the most intensely studied human genes and is often called the "guardian of the genome". The MDM2 protein is a cellular inhibitor of $\mathrm{p} 53$ that can bind the transactivation domain of p53 and down-regulate its ability to activate transcription [5]. The MDM2 gene is positively regulated by $\mathrm{p} 53$-mediated transcription forming a negative feedback loop to keep both proteins at normal levels. Recent data have suggested that dephosphorylation of MDM2 ser394 regulates attenuation of the p53-mediated response to DNA damage, and phosphorylation of MDM2 by ATM following DNA damage is necessary for p53 stabilization [6].

In the pathway triggered by aberrant growth signals, such as the oncogenes Ras or Myc, activation of the p53 network in humans depends on a protein called CDKN2A/ p14 ${ }^{\mathrm{ARF}}$ [7]. CDKN2A is a potent tumor suppressor that regulates the activities of the retinoblastoma protein and the P53 transcription factor. The CDKN2A protein binds to the MDM2 protein and negatively modulates its ubiquitin ligase activity, increasing the levels of p53 [8]. Gadd45A (growth arrest and DNA damage-induced45, alpha) is a DNA damage-responsive gene, which has been shown to participate in cell cycle arrest, DNA repair, cell survival and apoptosis in response to environmental and physiological stress, as well as to have a role in development and carcinogenesis [9]. GADD45A induction following DNA damage is rapid, transient and dose-dependent. GADD45A may play a role as an upstream effect factor in p53 stabilization following DNA damage [10].

The cytokinesis-block micronucleus (CBMN) assay is the most reliable method for measuring the micronuclei $(\mathrm{MN})$ in peripheral blood lymphocytes (PBLs). In this assay, PBLs are induced to divide in vitro in culture, and $\mathrm{MN}$ are scored in cells that have completed one nuclear division; these cells are recognized by their bi-nucleated (BN) appearance after cytokinesis is inhibited by cytochalasin-B. The CBMN method can reliably assess chromosome damage, including chromosome breakage and chromosome loss from occupational and environmental exposures. Some investigations have demonstrated that the frequency of $\mathrm{MN}$ is increased in the lymphocytes of individuals occupationally exposed to VC [11].

Previously, we conducted investigations of the genotoxicity of VC and the effect of genetic polymorphisms of genes involved in metabolism and DNA repair [11-13]. To the best of our knowledge, there have been few investigations of the effect of genetic polymorphisms of genes involved in cell cycle on CBMN frequencies in VC workers. Therefore, the aim of the present study was to determine whether p53 pathway polymorphisms involved in the cell cycle (p53 ins/del (rs17878362), p53 Arg72Pro C > G (rs1042522), MDM2 Del1518 (rs3730485), MDM2 SNP309 T > G (rs2279744), CDKN2A G > A (rs3088440), and GADD45A T > C (rs532446) modified chromosomal damage in VC-exposed workers.

\section{MATERIALS AND METHODS}

\section{Study subjects and epidemiological data}

After obtaining appropriate informed consents, we conducted personal interviews with structured questionnaires among the current workers of two PVC polymerization 
plants in Shanghai, China. The questionnaire included demographics, lifestyle, and occupational history. Smoking and drinking statuses were simple binary variables (yes or no). All subjects included met the following criteria:

- completed the questionnaire,

- provided a blood sample,

- completed CBMN tests and genotyping for all candidate genes.

The design and implementation of our study were approved by the Ethical Review Board of the School of Public Health, Fudan University.

Workers who had been exposed to VC for at least 1 year were defined as the exposed group, and logistic service workers and managers in the same factories who had not been exposed to $\mathrm{VC}$ or other occupational toxicants were defined as the non-exposed group. A total of 459 workers were included, with 310 in the exposed group and 149 in the non-exposed group, respectively. The age of the exposed group ranged from 20 to 59 years, (mean: 36.01 years). The age of the controls ranged from 24 to 60 years (mean: 44.91 years).

\section{CBMN assay}

The CBMN assay was performed according to the standard method described by Fenech [14]. Blood samples were collected by venipuncture in heparinized tubes and sent to a laboratory within a few hours of collection. A $0.5 \mathrm{ml}$ sample of heparin-anticoagulated whole blood was added to $4.5 \mathrm{ml}$ of the medium (RMRI1640). Cytochalasin-B (Sigma-Aldrich, St. Louis, MO) was added to each cell culture after $44 \mathrm{~h}$ at a concentration of $6 \mu \mathrm{g} / \mathrm{ml}$. After $28 \mathrm{~h}$, cultured lymphocyte cells were harvested and fixed with methanol and acetic acid at 4:1, and then the fixed cells were transferred to a glass slide. For the evaluation of chromosomal damage in each studied individual, 1000 bi-nucleated (BN) lymphocytes with wellpreserved cytoplasm were scored blindly by the same reader. In order to maintain quality control, we randomly repeated at least $10 \%$ of the samples to verify the results, and the results were $100 \%$ concordant.

\section{Exposure assessment}

VC air samples were collected at different worksites in the VC polymerization plants and analyzed by gas chromatography to determine $\mathrm{VC}$ air concentrations of the various worksites and estimate the cumulative exposure dose for each worker. We were able to calculate the cumulative exposure dose for each worker using the following equation:

$$
\begin{gathered}
\text { Cumulative exposure dose }(\mathrm{mg})= \\
=\sum\left(\mathrm{C} \times \mathrm{M} \times \mathrm{T} \times \mathrm{A} \times 70 \% / 10^{6}\right)
\end{gathered}
$$

where:

$\mathrm{C}$ - the geometric mean of the $\mathrm{VC}$ exposure concentration (in $\mathrm{mg} / \mathrm{m}^{3}$ ) for each month in a given workplace (calculated for all worksites);

$\mathrm{M}$ - the number of exposure months in a year for each $\mathrm{VC}$ worker;

$\mathrm{T}$ - duration of exposure per month (for $2 \mathrm{~h}$ exposure time during each working day, 20 days per month, for example, $\mathrm{T}=2400$ min exposure time per month);

A - alveolar ventilation (male average $=6500 \mathrm{ml} / \mathrm{min}$, female average $=4300 \mathrm{ml} / \mathrm{min}$, assuming $30 \%$ dead space).

\section{Genotyping of cell cycle control genes}

The genotypes were determined by the polymerase chain reaction and restriction fragment length polymorphism (PCRRFLP) method. Primers, amplified fragments, restriction patterns, and restriction enzymes used are listed in Table 1. The P53 rs17878362 polymorphism consists of 16-bp duplication in intron3. As a type of length of deletion (Del)/ insertion (Ins) polymorphism, the models of WW: Ins/Ins, WM: Del/Ins and MM: Del/Del were detected. The P53 rs1042522 (Ex4+119C > G: C and G alleles) polymorphism displays substitution of $\mathrm{C}$ to $\mathrm{G}$ in codon 72 of exon4 of the P53 gene, changing the amino acid from proline (Pro) to arginine (Arg) in the proline-rich domain of the P53 protein. MDM2 SNP309 polymorphism, a 121-bp PCR product was 
Table 1. Primers and restriction enzymes used for genotyping various single-nucleotide polymorphisms (SNP) in cell cycle control genes

\begin{tabular}{|c|c|c|c|c|}
\hline SNPs & Primer sequences & $\begin{array}{c}\text { Restriction } \\
\text { enzymes }\end{array}$ & $\begin{array}{l}\text { Length } \\
\text { (bp) }\end{array}$ & $\begin{array}{l}\text { Fragment size } \\
\text { (bp) }\end{array}$ \\
\hline P53intron3 (rs17878362) & $\begin{array}{l}\text { F: TGGGACTGACTTTCTGCTCTT } \\
\text { R: TCAAATCATCCATTGCTTGG }\end{array}$ & - & $196 / 180^{\mathrm{a}}$ & $\begin{array}{l}\text { WW: } 180 \\
\text { WM: } 180,196 \\
\text { MM: } 196\end{array}$ \\
\hline p53Arg72Pro C > G(rs1042522) & $\begin{array}{l}\text { F: GTCCCAAGCAATGGATGAT } \\
\text { R: CAAAAGCCAAGGAATACACG }\end{array}$ & Bsh1236I & 551 & $\begin{array}{l}\text { CC: } 551 \\
\text { CG: } 551,443,108 \\
\text { GG: } 443,108\end{array}$ \\
\hline MDM2Del1518 (rs3730485) & $\begin{array}{l}\text { F: TTCTGGTAGGCTGGGAAGCG } \\
\text { R:TGCGGTCTCATAAATTGAGGACAT }\end{array}$ & - & $216 / 176^{b}$ & $\begin{array}{l}\text { WW: } 216 \\
\text { WM: } 216,176 \\
\text { MM: } 176\end{array}$ \\
\hline MDM2SNP309 T > G(rs2279744) & $\begin{array}{l}\text { F: GATTTCGGACGGCTCTCGCGGC } \\
\text { R: CATCCGGACCTCCCGCGCTG }\end{array}$ & PstI & 122 & $\begin{array}{l}\text { TT: } 121 \\
\text { TG: } 121,104,17 \\
\text { GG: } 104,17\end{array}$ \\
\hline GADD45AT >C (rs532446) & $\begin{array}{l}\text { F: GCGAGAACGACATCAACA } \\
\text { R: TTAGTCACGGGAGGCAGT }\end{array}$ & MvaI & 432 & $\begin{array}{l}\text { TT: } 432 \\
\text { TC: } 432,306,126 \\
\text { CC: } 306,126\end{array}$ \\
\hline CDKN2AG > A (rs3088440) & $\begin{array}{l}\text { F: GCCTGTTTTCTTCTGCCCTCTG } \\
\text { R: CGAAAGCGGGGTGGGTGT }\end{array}$ & Bsu RI & 143 & $\begin{array}{l}\text { GG: } 108,35 \\
\text { GA: } 143,108,35 \\
\text { AA: } 143\end{array}$ \\
\hline
\end{tabular}

${ }^{a}$ The P53 rs17878362 polymorphism consists of 16-bp duplication in intron3. As a type of length of deletion (Del) / insertion (Ins) polymorphism, the models of WW: Ins/Ins, WM: Del/Ins and MM: Del/Del were detected.

${ }^{\mathrm{b}}$ For the Del1518 polymorphism, the primers were designed to perform direct PCR amplification. The 216-bp fragment containing the 40-bp insertion was assigned as $\mathrm{W}$, and the 176-bp fragment without the insertion was assigned as $\mathrm{M}$.

TT - wild-type; TG - heterozygote; GG - varient; TC - heterozygote; CC - varient; GA - heterozygote; AA - variant.

digested by PstI, the wild-type (SNP309T) allele produces a single 121-bp fragment and the variant (SNP309G) allele produces 2 fragments of 104- and 17-bp. For the Del1518 polymorphism, the primers were designed to perform direct PCR amplification. The 216-bp fragment containing the 40bp insertion was assigned as $\mathrm{W}$, and the 176-bp fragment without the insertion was assigned as M. In the GADD45A polymorphism, the wild-type (T) allele produces a single 432bp fragment and the variant $(\mathrm{C})$ allele produces 2 fragments of 306- and 126-bp. Cyclin-dependent kinase inhibitor (CD$\mathrm{KN} 2 \mathrm{~A}$ ) is an important tumor suppressor gene, p14ARF is an alternate reading frame (ARF) product of the CDKN2A locus. In the CDKN2A polymorphism, the $\mathrm{G}$ allele produced two fragments of 108-bp and 35-bp or the variant (A) allele produced a single 143-bp fragment. Approximately 50 ng of genomic DNA was amplified by GeneAmp 9600 (Perk in Elmer Corp, Waltham, MA) in a total volume of $15 \mu \mathrm{l}$ consisting of $0.4 \mu \mathrm{l}$ for each primer, $7.5 \mu \mathrm{l}$ of $2 \times \mathrm{PCR}$ Mix and $5.7 \mu \mathrm{l}$ of $\mathrm{ddH}_{2} \mathrm{O}$.

The PCR program was a five-minute denaturation step at $95^{\circ} \mathrm{C} ; 35$ cycles of $94^{\circ} \mathrm{C}$ for $30-50 \mathrm{~s}, 55-59^{\circ} \mathrm{C}$ for $30-50 \mathrm{~s}$, and $72^{\circ} \mathrm{C}$ for $30-50 \mathrm{~s}$ (according to the length of the fragment amplified), respectively; followed by the final extension step at $72^{\circ} \mathrm{C}$ for $10 \mathrm{~min}$. The PCR products were digested at $37^{\circ} \mathrm{C}$ for $16 \mathrm{~h}$ by the corresponding restriction enzymes, and the digested PCR products were then observed under a UV imaging system (Gel Doc 2000, Segrate, Milan, Italy). For quality control, at least ten percent of DNA samples were selected randomly for repetition of the procedures, and the concordance was $100 \%$. 


\section{Statistical analysis}

All statistical analyses were made using SAS software package (version 9.1). The Hardy-Weinberg equilibrium was tested for all genotypes. The influences of individual characteristics, cumulative exposure dose (CED), genotypes and interaction on the frequencies of CBMN cells per 1000 binucleated cells were determined using univariate and multiple Poisson regression analyses. All variables were transformed to categorical ones, with age division into $\leq 35$ year and $>35$ year, and CED being ranked in quartiles. The mean frequency ratio and its $95 \%$ confidence interval were estimated using:

$$
F R=e^{\beta}(e=2.71828)
$$

where:

$\beta$ - the regression coefficient in the Poisson model;

$\mathrm{FR}$ - indicated the ratio of the mean MN frequency in a study group compared with a reference one.

\section{RESULTS}

\section{Subject characteristics and risk estimates}

\section{for demographic and lifestyle factors}

Table 2 shows the distribution of subjects' characteristics and the MN frequency. In the VC non-exposed group, females had a lower MN frequency than males $(\mathrm{FR}=0.72,95 \%$ CI: $0.53-0.97, \mathrm{p}=0.03)$. No obvious differences were observed in terms of age, smoking status and alcohol drinking. In the exposed group, subjects aged over 35 years who were smokers had a higher risk than younger non-smokers $(\mathrm{FR}=1.74,95 \% \mathrm{CI}$ : $1.56-1.93, \mathrm{p}<0.001 ; \mathrm{FR}=1.33,95 \%$ CI: $1.20-1.47$, $\mathrm{p}<0.001$, respectively). In terms of gender and alcohol drinking, there was a slight increase in the female group and the group drinking alcohol, but it was not statistically significant.

Table 2. Micronuclei (MN) frequency among the VC-exposed workers, controls and the related risk estimates of various demographic characteristics

\begin{tabular}{|c|c|c|c|c|c|c|}
\hline \multirow[b]{2}{*}{ Variables } & \multicolumn{3}{|c|}{ Control } & \multicolumn{3}{|c|}{ Exposed } \\
\hline & $\mathrm{n}$ & $\begin{array}{c}\mathrm{MN} \pm \mathrm{SD} \\
(\% 0)\end{array}$ & $\mathrm{FR}^{\mathrm{a}}(95 \% \mathrm{CI})$ & $\mathrm{n}$ & $\begin{array}{c}\mathrm{MN} \pm \mathrm{SD} \\
(\% 0)\end{array}$ & FR $(95 \% \mathrm{CI})$ \\
\hline \multicolumn{7}{|l|}{ Age (years) } \\
\hline$\leq 35$ & 10 & $1.70 \pm 1.70$ & 1 & 151 & $3.50 \pm 2.60$ & 1 \\
\hline$>35$ & 139 & $1.24 \pm 1.42$ & $0.73(0.44-1.20)$ & 159 & $6.09 \pm 3.75$ & $1.74(1.56-1.93)^{* *}$ \\
\hline \multicolumn{7}{|l|}{ Gender } \\
\hline male & 88 & $1.44 \pm 1.33$ & 1 & 246 & $4.42 \pm 3.27$ & 1 \\
\hline female & 61 & $1.03 \pm 1.57$ & $0.72(0.53-0.97)$ & 64 & $4.94 \pm 3.54$ & $1.12(0.98-1.27)$ \\
\hline \multicolumn{7}{|l|}{ Smoking } \\
\hline no & 113 & $1.20 \pm 1.20$ & 1 & 147 & $4.12 \pm 3.25$ & 1 \\
\hline yes & 36 & $1.50 \pm 2.04$ & $1.25(0.91-1.71)$ & 163 & $5.47 \pm 3.58$ & $1.33(1.20-1.47)^{* *}$ \\
\hline \multicolumn{7}{|l|}{ Drinking } \\
\hline no & 119 & $1.19 \pm 1.39$ & 1 & 165 & $4.79 \pm 3.53$ & 1 \\
\hline yes & 30 & $1.60 \pm 1.63$ & $1.34(0.97-1.86)$ & 145 & $4.96 \pm 3.46$ & $1.04(0.94-1.15)$ \\
\hline Total & 149 & $1.28 \pm 1.44$ & 1 & 310 & $4.83 \pm 3.49$ & $3.79(3.26-4.11)^{*}$ \\
\hline
\end{tabular}

VC - vinyl chloride; SD - standard deviation; FR - frequency ratio; CI - confidence interval.

a Refers to frequency ratio.

* FR of the total 310 exposed workers compared with 149 controls, $\mathrm{p}<0.001$.

** In the VC-exposed workers, FRs of older workers compared with the younger ones, and of smokers compared with the non-smokers, $\mathrm{p}<0.001$. 


\section{VC exposure increased the MN frequencies}

Based on CED (range: 16.78-272 $247.29 \mathrm{mg}$ ), all subjects were stratified into 5 levels of approximately equal size among the 4 levels of exposure:

- level 0 (non-exposed),

- level $1(\leq 637 \mathrm{mg})$,

- level 2 (637-4566 mg),

- level 3 (4566-13000 mg),

- level 4 ( > $13000 \mathrm{mg}$ ).

The results of the univariate analysis of CED and $\mathrm{MN}$ (Table 3) showed that the MN frequency was significantly elevated for all levels of exposure (level 1 to level 4) compared with the non-exposed one (level 0):

- for level 1 (FR $=2.32,95 \%$ CI: 1.80-3.01, $\mathrm{p}<0.001$ ),

- for level 2 (FR $=3.18,95 \% \mathrm{CI}: 2.50-4.06, \mathrm{p}<0.001$ ),

- for level 3 (FR = 3.85, 95\% CI: 3.06-4.88, $\mathrm{p}<0.001$ ),

- for level 4 (FR $=5.83,95 \% \mathrm{CI}: 4.69-7.30, \mathrm{p}<0.001$ ).

After adjusting for age, gender, smoking and alcohol drinking, the results of the multivariate Poisson regression analyses were highly consistent with the crude results.

\section{MN frequencies related to the genotype} in the VC-exposed workers

The genotype distributions at each locus were consistent with the Hardy-Weinberg equilibrium. Table 4 displays the $\mathrm{MN}$ distribution of various genotypes, as well as the crude and adjusted FR (adjusted for age, gender, smoking and alcohol drinking status, as well as CED).

Except the p53 Arg72Pro gene polymorphism, all of the other 4 SNPs showed that the variant heterozygote and the variant homozygote were at higher risk for chromosomal damage compared with their wild-type genotype:

- p53rs17878362 $(\mathrm{FR}=1.75,95 \%$ CI: 1.57-1.95, $\mathrm{p}<0.001)$

- MDM2 Del1518 rs3730485 (FR = 1.44, 95\% CI: 1.27 $1.63, \mathrm{p}<0.001)$;

- MDM2 rs2279744 (FR = 1.92, 95\% CI: 1.65-2.25, $\mathrm{p}<0.001)$

- GADD45Ars532446 (FR = 1.27, 95\% CI: 1.12-1.43, $\mathrm{p}<0.001)$.

On the other hand, individuals carrying the CDKN2A rs3088440 GA +AA genotype had a reduced risk compared with those carrying the wild-type GG genotype $(\mathrm{FR}=0.63,95 \% \mathrm{CI}: 0.56-0.70, \mathrm{p}<0.001)$.

\section{VC exposure levels and genotypes had an effect on the MN frequencies}

The multiple Poisson analysis was used to examine the potential effects of CED and gene polymorphisms with adjustment for age, gender, smoking, and drinking (Table 5).

Table 3. Micronuclei (MN) frequency and the related risk estimates of VC-exposed workers and controls at different levels of cumulative exposure dose

\begin{tabular}{lccccc}
\hline Exposure level & $\begin{array}{c}\mathrm{CED}^{\mathrm{a}} \\
(\mathrm{mg})\end{array}$ & $\begin{array}{c}\text { Workers } \\
(\mathrm{n})\end{array}$ & $\begin{array}{c}\mathrm{MN} \pm \mathrm{SD} \\
(\% 0)\end{array}$ & $\begin{array}{c}\mathrm{FR} \\
(95 \% \mathrm{CI})\end{array}$ & $\begin{array}{c}\mathrm{FR}^{\mathrm{b}} \\
(95 \% \mathrm{CI})\end{array}$ \\
\hline 0 & 0 & 149 & $1.28 \pm 1.44$ & 1.00 & 1.00 \\
1 & $\leq 637$ & 78 & $2.96 \pm 1.98$ & $2.32(1.80-3.01)^{*}$ & $2.74(2.19-3.45)^{*}$ \\
2 & $637-4566$ & 77 & $4.05 \pm 2.93$ & $3.18(2.50-4.06)^{*}$ & $3.59(2.93-4.41)^{*}$ \\
3 & $4566-13000$ & 78 & $4.91 \pm 3.19$ & $3.85(3.06-4.88)^{*}$ & $4.27(3.54-5.16)^{*}$ \\
4 & $>13000$ & 77 & $7.43 \pm 3.94$ & $5.83(4.69-7.30)^{*}$ & $6.03(5.06-7.23)^{*}$ \\
\hline
\end{tabular}

${ }^{a} \mathrm{CED}$ - cumulative exposure dose, refers to cumulate exposure dose. The workplace CED was calculated according to the equation, which was described in materials and methods.

${ }^{\mathrm{b}}$ Refers to the frequency ratio. FRs were adjusted for age, gender, smoking and alcohol drinking status.

* Compared with the controls, $\mathrm{p}<0.001$.

Other abbreviations as in Table 2. 
Table 4. Distribution of micronuclei (MN) frequency and the related risk estimates among VC-exposed workers by the genetic polymorphism of cell cycle control genes

\begin{tabular}{|c|c|c|c|c|}
\hline Genotype & $\begin{array}{l}\text { Workers } \\
(\mathrm{n})\end{array}$ & $\begin{array}{c}\mathrm{MN} \pm \mathrm{SD} \\
(\% \circ)\end{array}$ & $\begin{array}{c}\text { FR } \\
(95 \% \mathrm{CI}) \\
\end{array}$ & $\begin{array}{c}\mathrm{FR}^{\mathrm{a}} \\
(95 \% \mathrm{CI})\end{array}$ \\
\hline \multicolumn{5}{|l|}{ p53intron3 (rs17878362) } \\
\hline WW & 168 & $3.54 \pm 3.27$ & 1.00 & 1.00 \\
\hline $\mathrm{WM}+\mathrm{MM}$ & 141 & $5.92 \pm 3.31$ & $1.67(1.50-1.86)^{*}$ & $1.75(1.57-1.95)^{*}$ \\
\hline \multicolumn{5}{|l|}{ p53Arg72Pro(rs1042522) } \\
\hline $\mathrm{CC}$ & 233 & $5.01 \pm 2.94$ & 1.00 & 1.00 \\
\hline $\mathrm{CG}+\mathrm{GG}$ & 76 & $4.79 \pm 3.65$ & $0.95(0.85-1.07)$ & $0.92(0.82-1.04)$ \\
\hline \multicolumn{5}{|c|}{ MDM2Del1518(rs3730485) } \\
\hline WW & 219 & $3.88 \pm 3.19$ & 1.00 & 1.00 \\
\hline $\mathrm{WM}+\mathrm{MM}$ & 83 & $5.11 \pm 3.53$ & $1.32(1.17-1.49)^{*}$ & $1.44(1.27-1.63)^{*}$ \\
\hline \multicolumn{5}{|l|}{ MDM2309(rs2279744) } \\
\hline $\mathrm{TT}$ & 232 & $2.47 \pm 2.15$ & 1.00 & 1.0 \\
\hline $\mathrm{TG}+\mathrm{GG}$ & 78 & $5.63 \pm 3.49$ & $2.27(1.96-2.65)^{*}$ & $1.92(1.65-2.25)^{*}$ \\
\hline \multicolumn{5}{|l|}{ GADD45A (rs532446) } \\
\hline $\mathrm{TT}$ & 214 & $4.09 \pm 3.16$ & 1.00 & 1.00 \\
\hline $\mathrm{CT}+\mathrm{CC}$ & 82 & $5.04 \pm 3.61$ & $1.23(1.09-1.40)^{*}$ & $1.27(1.12-1.43)^{*}$ \\
\hline \multicolumn{5}{|l|}{ CDKN2A(rs3088440) } \\
\hline GG & 169 & $6.19 \pm 3.48$ & 1.00 & 1.00 \\
\hline $\mathrm{GA}+\mathrm{AA}$ & 102 & $3.93 \pm 3.35$ & $0.64(0.57-0.71)^{*}$ & $0.63(0.56-0.70)^{*}$ \\
\hline
\end{tabular}

WW - Ins/Ins; WM - Del/Ins; MM - Del/Del.

${ }^{a}$ Refers to the frequency ratios. FRs were adjusted for age, gender, smoking and alcohol drinking status, and the cumulative exposure dose.

* Compared with major alleles for each genotype case, $\mathrm{p}<0.001$.

Other abbreviations as in Table 2.

Individuals carrying the MDM2 SNP309 TG+GG genotype had an effect on level 1, level 2, level 3 and level 4 of CED (FR $=1.56,95 \%$ CI: $1.00-2.34, \mathrm{p}<0.05 ; \mathrm{FR}=2.62$, 95\% CI: $1.65-4.15, \mathrm{p}<0.001 ; \mathrm{FR}=1.95,95 \%$ CI: 1.24 $3.05, \mathrm{p}<0.05 ; \mathrm{FR}=2.81,95 \% \mathrm{CI}: 1.72-4.66 \mathrm{p}<0.001$, respectively) compared with the individuals with the wildtype TT genotype.

For the GADD45A gene polymorphism, an obvious interaction was only observed for level 4 CED, and subjects with the $\mathrm{CT}$ and $\mathrm{CC}$ alleles had a higher risk than the TT subjects $(\mathrm{FR}=1.54,95 \% \mathrm{CI}: 1.06-2.22, \mathrm{p}<0.05)$. Individuals carrying the gene CDKN2A GA and AA genotypes had an effect on level 2 and level 4 CED (FR $=0.56$,
95\% CI: $0.38-0.83, p<0.05$; FR $=0.60,95 \%$ CI: $0.42-$ $0.84, \mathrm{p}<0.05$, respectively) compared with those carrying the GG genotype.

\section{DISCUSSION}

The aim of this study was to explore the association between polymorphisms of DNA cell cycle genes and chromosomal damage induced by VC. Our results confirmed that VC exposure is associated with the risk of chromosomal damage as determined by the MN assay. Moreover, age and smoking had an effect on chromosomal damage. We also observed that some of the gene polymorphisms 
involved in the p53-pathway may have an impact on individual susceptibility to DNA damage.

The CBMN assay used in this study is the preferred method for measuring MN in cultured human cells. The key advantage of the micronuclei is that they are easier to observe and count, and the methodology is simple and facilitates rapid cells assessment. Micronuclei come from chromosome fragments that are not included in the main nuclei. This technique uses cytochalasin-B, which arrests division of the cytoplasm or cytokinesis without inhibiting nuclear division, so it enables such cells to be recognized by their binucleate appearance [15]. Therefore, the MN represents chromosome breakage and chromosome loss. In our study, the results showed that workers exposed to $\mathrm{VC}$ had significantly higher $\mathrm{MN}$ frequencies than the controls. The results of univariate Poisson regression analyses indicated that older workers ( $>35$ year) and smoking workers had higher MN frequencies. No significant difference in the MN frequency was detected in association with the alcohol drinking status or gender, but the associations, if any, may have been masked by the magnitude of the association with VC exposure or the limited number of female workers in the VC-exposed group.

The tumor suppressor p53 gene is the most frequently mutated gene in human cancer and has been implicated in maintaining genomic fidelity by controlling cellular response to genotoxic stress [10]. The $16 \mathrm{bp}$ insertion and deletion polymorphisms (rs17878362) in intron3 may participate in the regulation of the p53 expression and thus play a role in the stability of the $\mathrm{p} 53$ protein. It has been reported that mutations and deletions of the p53 gene can increase the hepatocellular carcinoma (HCC) risk [16]. The presence of the biomarkers for variant p53 was found to be highly significantly associated with cumulative VC exposure [17]. Thus, genetic polymorphisms in 553 have been thought to be possible biomarkers of susceptibility to VC. In our study, we found that individuals with the deletion allele were subjected to a higher risk than those with the insertion allele 
$(\mathrm{FR}=1.75,95 \%$ CI: $1.57-1.95, \mathrm{p}<0.001)$. A common polymorphism at codon72 (Arg72Pro, rs1042522) of the p53 gene has recently been reported to be a risk factor for some cancers and chronic diseases like the coronary artery disease [18]. However, there were no associations noted between the MN frequency and the Arg72Pro polymorphism in our study after the adjustments for age, gender, smoking status, alcohol drinking and cumulative VC exposure. Our findings support previous data showing lack of an association between the p53 $\mathrm{Arg} 72$ Pro polymorphism and the MN frequency [12].

The $\mathrm{p} 53$ protein is regulated by an ubiquitin ligase, the MDM2 protein, which binds to $\mathrm{p} 53$, blocking its function as a transcription factor, and targeting the p53 protein for mediated degradation. In the MDM2 gene, a SNP (SNP309) results in a nucleotide change from the wildtype thymine $(\mathrm{T})$ to guanine $(\mathrm{G})$ in the intronic promoter/ enhancer region [19]. Previous studies have indicated that this G allele of SNP309 is correlated with higher levels of MDM2 RNA and the protein, which increases the risk for tumorigenesis [20,21].

In agreement with these findings, our study also found a significant increase in the MN frequency in the presence of a variant allele of the MDM2 SNP309 (rs2279744) polymorphism in VC-exposed workers. MDM2 Del1518 is a 40-bp insertion/deletion polymorphism at a constitutive promoter of MDM2, which can influence the gene transcription. This polymorphism has been studied in relation to cancer and chronic benzene poisoning [22,23]. Our results suggested that the MDM2 Del1518 polymorphism had an effect on susceptibility to VC. The VC-exposed workers carrying the Del1518 WM+MM genotype had a 1.44 fold increased risk of the MN frequency compared with those carrying the Del1518 WW genotype.

The CDKN2Agene interacts directly with MMD2, suppressing the ubiquitin ligase activity of MDM2, and consequently inhibiting MDM2-mediated degradation of p53. Such interaction results in stabilization and accumulation of p53. Thus, genetic alteration of CDKN2A may affect cell cycle regulation and apoptosis by disrupting the p53 pathway [24]. Researchers have observed that CDKN2A polymorphisms were associated with a moderately but significantly increased risk of developing a second primary malignancy for patients who had an index squamous cell carcinoma of the head and neck [25]. However, in our study, the workers who possessed the variant genotypes had a significantly decreased risk of the MN frequency compared with the workers with the corresponding homozygous wild-type genotype. This is perhaps due to the fact that the CDKN2A gene can interact with several different proteins and transcription factors or due to the existence of the combined effect of other CDKN2A polymorphisms that were not accounted for.

GADD45A is a genotoxic stress-responsive gene induced by a wide spectrum of DNA-damaging agents including IR, UV and many alkylators [26]. Regulation of GADD45A induction after DNA damage is complex and may involve both p53-dependent and independent signaling pathways. Abnormal GADD45A expression levels have been observed in resectable invasive pancreatic ductal carcinomas, and GADD45A is frequently mutated, which combined with the p53 status affects the survival of these patients [27]. One study has shown that the GADD45 proteins can act as sensors of oncogenic stress in breast carcinogenesis [28]. In the present study, a SNP in the GADD45A gene, a T-to-C change in intron 3 (rs532446) was significantly associated with the $\mathrm{MN}$ frequency. Therefore, this GADD45A polymorphism may also be involved in the susceptibility to DNA damage induced by VC. Genotoxicity is a complex process involving interactions between multiple factors of endogenous and exogenous origin. Although genetic polymorphisms alone can play an important role in the development of diseases, most chronic and complex illnesses are likely to be caused by interactions between environmental exposures and genetic polymorphisms. 
In this study, the results of CED and gene polymorphisms were assessed in a multiplicative model. Positive effects with CED were observed with MDM2 SNP309 T > G (rs2279744) and GADD45A T > C (rs532446), and a negative one was seen in CDKN2A G > A (rs3088440). It is normally difficult to study the subtle phenotypic effects caused by a single gene polymorphism due to the influence of the environment and other related genes.

Therefore, studying the main effect and the interaction of different related genes in the same pathway is necessary, but it can require larger sample sizes. Although all the chosen genes in this study play their roles in cell cycle control through the p53 pathway, determining the environment-gene interactions or genetic modification effects is limited by our relatively small sample size, which restricts the number of covariates fitted into the regression model and the statistical power of the study. Therefore, studies with larger sample sizes are needed to verify our findings. Similarly, gene-gene interactions were not analyzed in this study because of the limited sample size and the fact that such a strong environmental effect may mask weaker gene-gene modification effects. The design of future studies can hopefully take these limitations into account.

In conclusion, this is the first time that genetic variants in the cell cycle control pathway associated with p53 have been shown to be involved in DNA damage caused by $\mathrm{VC}$ exposure. However, the interaction between genetic polymorphisms and lifestyle-related risk factors among VC-exposed workers is complicated, and the present study is limited in its ability to fully delineate the genegene and gene-environment interactions involved in this process. In order to better understand the mechanisms of $\mathrm{VC}$-induced genotoxicity and carcinogenicity, it will be important to carry out additional studies to validate our findings and to further elucidate the role of genes variants in the p53 pathway associated with VC-induced chromosomal damage.

\section{REFERENCES}

1. Bolt HM. Vinyl chloride-a classical industrial toxicant of new interest. Crit Rev Toxicol. 2005;35(4):307-23, http://dx.doi. org/10.1080/10408440490915975.

2. Byren D, Engholm G, Englund A, Westerholm P. Mortality and cancer morbidity in a group of Swedish VCM and PCV production workers. Environ Health Perspect. 1976;17: $167-70$

3. El Ghissassi F, Barbin A, Bartsch H. Metabolic activation of vinyl chloride by rat liver microsomes: Low-dose kinetics and involvement of cytochrome P450 2E1. Biochem Pharmacol. 1998;55(9):1445-52, http://dx.doi.org/10.1016/s00062952(97)00645-x.

4. Zhu S, Wang A, Xia Z. Polymorphisms of DNA repair gene XPD and DNA damage of workers exposed to vinylchloride monomer. Int J Hyg Environ Health. 2005;208(5):383-90, http://dx.doi.org/10.1016/j.jheh.2005.05.002.

5. Kussie PH, Gorina S, Marechal V, Elenbaas B, Moreau J, Levine AJ, et al. Structure of the MDM2 oncoprotein bound to the p53 tumor suppressor transactivation domain. Science. 1996;274(5289):948-53, http://dx.doi.org/10.1126/science.274.5289.948.

6. Gannon HS, Woda BA, Jones SN. ATM phosphorylation of Mdm2 Ser394 regulates the amplitude and duration of the DNA damage response in mice. Cancer Cell. 2012;21(5):66879, http://dx.doi.org/10.1016/j.ccr.2012.04.011.

7. Vogelstein B, Lane D, Levine AJ. Surfing the p53 network. Nature. 2000;408(6810):307-10, http://dx.doi. org $/ 10.1038 / 35042675$.

8. Honda R, Yasuda H. Association of p19(ARF) with Mdm2 inhibits ubiquitin ligase activity of Mdm2 for tumor suppressor p53. Embo J. 1999;18(1):22-7, http://dx.doi.org/10.1093/ emboj/18.1.22.

9. Liebermann DA, Tront JS, Sha X, Mukherjee K, MohamedHadley A, Hoffman B. Gadd45 stress sensors in malignancy and leukemia. Crit Rev Oncog. 2011;16(1-2):129-40, http:// dx.doi.org/10.1615/CritRevOncog.v16.i1-2.120. 
10. Jin S, Mazzacurati L, Zhu X, Tong T, Song Y, Shujuan S, et al. Gadd45a contributes to p53 stabilization in response to DNA damage. Oncogene. 2003;22(52):8536-40. http:// dx.doi.org/10.1038/sj.onc.1206907.

11. Wang Q, Ji F, Sun Y, Qiu YL, Wang W, Wu F, et al. Genetic polymorphisms of XRCC1, HOGG1 and MGMT and micronucleus occurrence in Chinese vinyl chloride-exposed workers. Carcinogenesis. 2010;31(6):1068-73, http://dx.doi. org/10.1093/carcin/bgq075.

12. Ji F, Wang W, Xia ZL, Zheng YJ, Qiu YL, Wu F, et al. Prevalence and persistence of chromosomal damage and susceptible genotypes of metabolic and DNA repair genes in Chinese vinyl chloride-exposed workers. Carcinogenesis. 2010;31(4):648-53, http://dx.doi.org/10.1093/carcin/bgq015.

13. Wang W, Qiu YL, Ji F, Liu J, Wu F, Miao WB, et al. Genetic polymorphisms in metabolizing enzymes and susceptibility of chromosomal damage induced by vinyl chloride monomer in a Chinese worker population. J Occup Environ Med. 2010;52(2):163-8, http://dx.doi.org/10.1097/ JOM.0b013e3181cac00b.

14. Fenech M. In vitro micronucleus technique to predict chemosensitivity. Methods Mol Med. 2005;111:3-32, http:/ dx.doi.org/10.1385/1-59259-889-7:003.

15. Fenech M. The cytokinesis-block micronucleus technique and its application to genotoxicity studies in human populations. Environ Health Perspect. 1993;101(Suppl 3):101-7, http://dx.doi.org/10.2307/3431708.

16. Staib F, Hussain SP, Hofseth LJ, Wang XW, Harris CC. TP53 and liver carcinogenesis. Hum Mutat. 2003;21(3):201-16, http://dx.doi.org/10.1002/humu.10176.

17. Schindler J, Li Y, Marion MJ, Paroly A, Brandt-Rauf PW. The effect of genetic polymorphisms in the vinyl chloride metabolic pathway on mutagenic risk. J Hum Genet. 2007;52(5):448-55, http://dx.doi.org/10.1007/s10038007-0134-5

18. Manfredi S, Masetti S, Botto N, Colombo MG, Terrazzi M, Vassalle C, et al. P53 codon 72 polymorphism in coronary artery disease: no evidence for association with increased risk or micronucleus frequency. Environ Mol Mutagen. 2002;40(2):110-5, http://dx.doi.org/10.1002/em.10098.

19. Bond GL, $\mathrm{Hu} \mathrm{W}$, Bond EE, Robins H, Lutzker SG, Arva NC, et al. A single nucleotide polymorphism in the MDM2 promoter attenuates the p53 tumor suppressor pathway and accelerates tumor formation in humans. Cell. 2004;119(5):591-602， http://dx.doi.org/10.1016/ j.cell.2004.11.022.

20. Bond GL, Hirshfield KM, Kirchhoff T, Alexe G, Bond EE, Robins H, et al. MDM2 SNP309 accelerates tumor formation in a gender-specific and hormone-dependent manner. Cancer Res. 2006;66(10):5104-10, http://dx.doi. org/10.1158/0008-5472.can-06-0180.

21. Hong Y, Miao X, Zhang X, Ding F, Luo A, Guo Y, et al. The role of P53 and MDM2 polymorphisms in the risk of esophageal squamous cell carcinoma. Cancer Res. 2005;65(20):9582-7, http://dx.doi.org/10.1158/0008-5472. can-05-1460.

22. Dong D, Gao X, Zhu Z, Yu Q, Bian S, Gao Y. A 40-bp insertion/deletion polymorphism in the constitutive promoter of MDM2 confers risk for hepatocellular carcinoma in a Chinese population. Gene. 2012;497(1):66-70, http://dx.doi. org/10.1016/j.gene.2012.01.004.

23. Sun P, Zhang Z, Wan J, Zhao N, Jin X, Xia Z. Association of genetic polymorphisms in GADD45A, MDM2, and p14 ARF with the risk of chronic benzene poisoning in a Chinese occupational population. Toxicol Appl Pharmacol. 2009;240(1):66-72, http://dx.doi.org/10.1016/ j.taap.2009.07.003.

24. Li Y, He L, Bruce A, Parihar K, Ingram A, Liu L, et al. p14ARF inhibits the growth of p53 deficient cells in a cellspecific manner. Biochim Biophys Acta. 2006;1763(8):78796, http://dx.doi.org/10.1016/j.bbamcr.2006.04.011.

25. Zhang Y, Sturgis EM, Zafereo ME, Wei Q, Li G. p14ARF genetic polymorphisms and susceptibility to second primary malignancy in patients with index squamous cell carcinoma of the head and neck. Cancer. 2011;117(6):1227-35, http:// dx.doi.org/10.1002/cncr.25605. 
26. Hildesheim J, Bulavin DV, Anver MR, Alvord WG, Hollander MC, Vardanian L, et al. Gadd45a protects against UV irradiation-induced skin tumors, and promotes apoptosis and stress signaling via MAPK and p53. Cancer Res. 2002;62(24):7305-15.

27. Yamasawa K, Nio Y, Dong M, Yamaguchi K, Itakura M. Clinicopathological significance of abnormalities in Gadd45 expression and its relationship to $\mathrm{p} 53$ in human pancreatic cancer. Clin Cancer Res. 2002;8(8):2563-9.

28. Tront JS, Huang Y, Fornace AJ Jr., Hoffman B, Liebermann DA. Gadd45a functions as a promoter or suppressor of breast cancer dependent on the oncogenic stress. Cancer Res. 2010;70(23):9671-81, http://dx.doi.org/10.1158/00085472.can-10-2177.

This work is available in Open Access model and licensed under a Creative Commons Attribution-NonCommercial 3.0 Poland License - http://creativecommons.org/ licenses/by-nc/3.0/pl/deed.en. 